\title{
Gambaran histologik usus halus pada hewan coba selama 24 jam postmortem
}

\author{
${ }^{1}$ Victori J. Theodore \\ ${ }^{2}$ Sunny Wangko, \\ ${ }^{2}$ Sonny. J. R. Kalangi
}

\author{
${ }^{1}$ Kandidat Skripsi Fakultas Kedokteran Universitas Sam Ratulangi Manado \\ ${ }^{2}$ Bagian Anatomi Histologi Fakultas Kedokteran Universitas Sam Ratulangi Manado \\ Email: vict.theodore12170@gmail.com
}

\begin{abstract}
Studies about histological changes in small intestine are still very limited. This study was aimed to obtain the histological changes of the small intestine in several time intervals during 24 hours postmortem. This was a descriptive observational study using domestic pig as model. Samples were obtained from the ileum section of the small intestine, taken at 0 hour, 1 hour, 2 hours, 3 hours, 4 hours, 5 hours, 6 hours, 7 hours, 8 hours, 9 hours, 12 hours, 14 hours, 16 hours, 18 hours, 20 hours, 22 hours, and 24 hours postmortem. The results showed that the earliest histological change was identified at 0 hours postmortem as congestion of the intestinal glands and formation of subepithelial cell spaces, followed by destruction of basal membranes of the glands at 3 hours postmortem, lysis of the glands at 16 hours postmortem. At 18-24 hours postmortem, almorst all intestinal glands could not be identified. Conclusion: The earliest histological change of small intestine was identified at 0 hours postmortem as congestion of the intestinal glands, followed by necrosis of the glands at 3 hours postmortem, and lysis of the glands at 16 hours postmortem.
\end{abstract}

Keywords: small intestine, autolysis, histological changes, postmortem

\begin{abstract}
Abstrak: Studi mengenai perubahan gambaran histologik usus halus postmortem masih sangat terbatas. Penelitian ini bertujuan untuk mendapatkan gambaran histologik usus halus berdasarkan variasi waktu selama 24 jam postmortem. Jenis penelitian ialah deskriptif observasional dengan menggunakan babi domestik sebagai hewan coba. Sampel diambil dari bagian ileum usus halus pada interval waktu: 0 jam, 1 jam, 2 jam, 3 jam, 4 jam, 5 jam, 6 jam, 7 jam, 8 jam, 9 jam, 12 jam, 14 jam, 16 jam, 18 jam, 20 jam, 22 jam, dan 24 jam postmortem. Hasil penelitian ini memperlihatkan bahwa perubahan histologik usus halus babi mulai teridentifikasi pada 0 jam postmortem berupa kongesti kelenjar intestinal, diikuti oleh kerusakan struktur membran basalis kelenjar pada 3 jam postmortem, dan lisis sel-sel kelenjar pada 16 jam postmortem. Pada 18-24 jam postmortem, hampir seluruh kelenjar intestinal tidak dapat diidentifikasi. Simpulan: Perubahan histologik awal dari usus halus dapat diidentifikasi pada 0 jam postmortem berupa kongesti kelenjar intestinal, diikuti oleh kerusakan struktur membran basalis 3 jam postmortem, dan lisis kelenjar pada 16 jam postmortem.
\end{abstract}

Kata kunci: usus halus, autolisis, postmortem, waktupostmortem, perubahan histologik postmortem

Kematian (mortem) adalah suatu keadaan dengan semua fungsi vital tubuh yang berhenti secara permanen. ${ }^{1}$ Salah satu pemeriksaan untuk mengetahui interval waktu postmortem yaitu pemeriksaan histopatologik. ${ }^{2}$

Usus halus (intestinum tenue) merupakan saluran panjang berkelok-kelok 
dengan panjang kira-kira 5-7 meter yang merupakan bagian saluran pencernaan terpanjang. Secara anatomik, usus halus dibagi menjadi 3 bagian, yaitu: duodenum, jejunum, dan ileum. ${ }^{3,4}$

Duodenum merupakan bagian terpendek dari usus halus. Vili di bagian ini tampak lebar, tinggi, dan banyak, dengan sedikit sel goblet pada lapisan epitel. Jejunum memiliki vili yang lebih pendek, lebih sempit, dan lebih sedikit daripada duodenum, sedangkan sel goblet pada epitel jumlahnya lebih banyak. Ileum mengandung sedikit vili yang sempit dan pendek; selain itu, epitel pada ileum mengandung lebih banyak sel goblet dibandingkan dengan duodenum dan jejunum. ${ }^{3}$

Penelitian postmortem mengenai usus halus yang dapat digunakan sebagai penentuan waktu kematian masih belum banyak dilaporkan atau dipublikasikan, dan umumnya menggunakan hewan coba tikus. Penelitian ini menggunakan babi sebagai hewan coba karena babi memiliki karakteristik anatomi dan fisiologi yang menyerupai manusia. ${ }^{5}$

\section{METODE PENELITIAN}

Jenis penelitian ini ialah deskriptif observasional. Penelitian ini dilakukan di Bagian Anatomi-Histologi Fakultas Kedokteran Manado pada bulan November 2015 sampai dengan Januari 2016. Hewan coba yang digunakan ialah satu ekor babi dengan berat $20 \mathrm{~kg}$ dengan kriteria inklusi yaitu babi tampak sehat, tidak terdapat riwayat penyakit baik saat penelitian maupun sebelumnya, dan tidak terdapat tanda-tanda cedera pada kulit.

\section{Prosedur penelitian}

Hewan coba dimatikan dengan cara ditusuk pada jantung. Setelah hewan coba berhenti bernapas, dicatat waktu kematian. Dilakukan pengambilan sampel jaringan usus halus pada segmen ileum dengan interval waktu: 0 jam, 1 jam, 2 jam, 3 jam, 4 jam, 5 jam, 6 jam, 7 jam, 8 jam, 9 jam, 12 jam, 14 jam, 16 jam, 18 jam, 20 jam, 22 jam, 24 jam postmortem. Setiap sampel difiksasi dengan formalin dan disiapkan untuk pembuatan preparat histologik dengan pewarnaan hematoxylin eosin. Pengamatan preparat menggunakan mikroskop cahaya Olympus CX21FS1 pembesaran 40x, 100x, dan 400x dan Optilab viewer.

\section{HASIL PENELITIAN}

Gambaran mikroskopik ileum babi 0 jam postmortem (400x) menunjukkan adanya kongesti dan pada sebagian kelenjar intestinal mulai terbentuk ruang subepitel (Gambar 1).

Gambaran mikroskopik ileum babi 2 jam postmortem (400x) menunjukkan ruang subepitel pada sebagian besar kelenjar intestinal yang makin meluas dengan lumen kelenjar melebar. Sebagian kelenjar memperlihatkan sel-sel epitel kelenjar tampak gelap dan tersusun padat sehingga lumen kelenjar tidak tampak (Gambar 2).

Gambaran mikroskopik ileum babi 3 jam postmortem (400x) menunjukkan membrana basalis pada sebagian kelenjar tampak tidak utuh (Gambar 3).

Gambaran mikroskopik ileum babi 12 jam postmortem (400x) menunjukkan sebagian besar membran basalis kelenjar intestinal telah mengalami kerusakan (Gambar 4).

Gambaran mikroskopik ileum babi 16 jam postmortem (400x) menunjukkan selsel kelenjar intestinal mulai mengalami lisis (Gambar 5).

Gambaran mikroskopik ileum babi 24 jam postmortem (40x) menunjukkan sebagian besar kelenjar intestinal telah mengalami lisis (Gambar 6). 


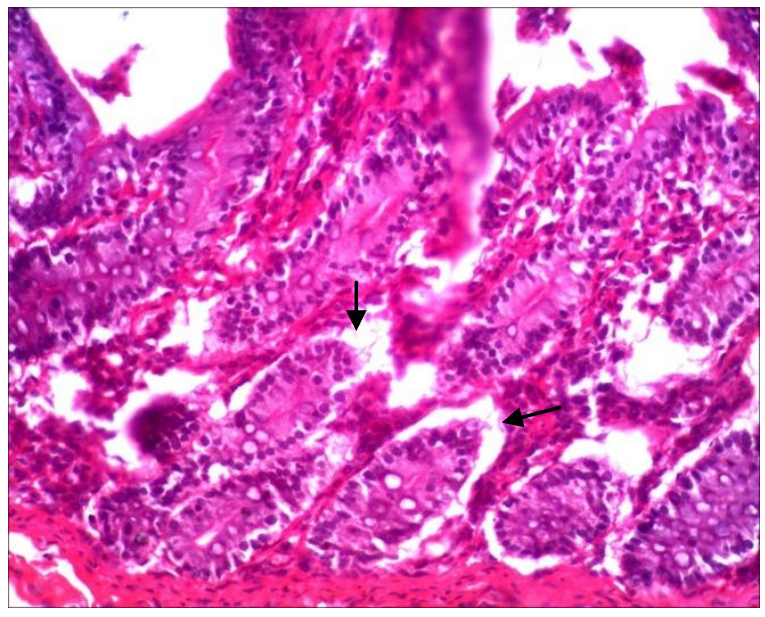

Gambar 1. Ileum babi, 0 jam postmortem. Pada sebagian kelenjar intestinal mulai terbentuk ruang subepitel (anak panah) (400x).

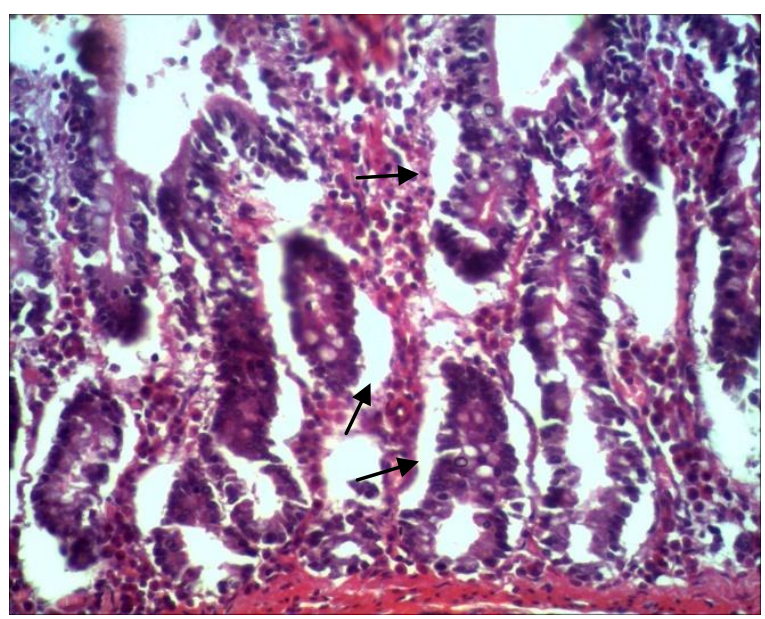

Gambar 3. Ileum babi 3 jam postmortem. Membrana basalis pada sebagian kelenjar tampak tidak utuh (anak panah) (400x).

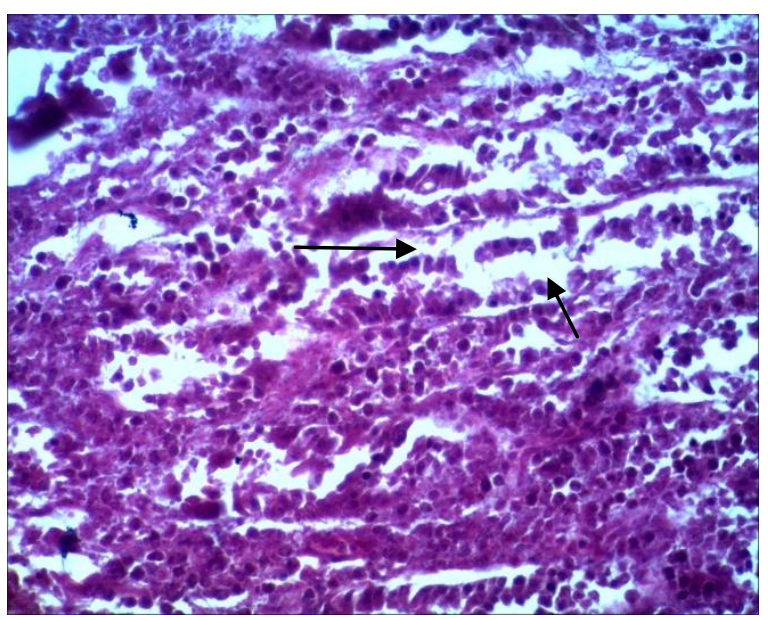

Gambar 5. Ileum babi 16 jam postmortem. Sel-sel kelenjar intestinal mulai mengalami lisis (anak panah) (400x).

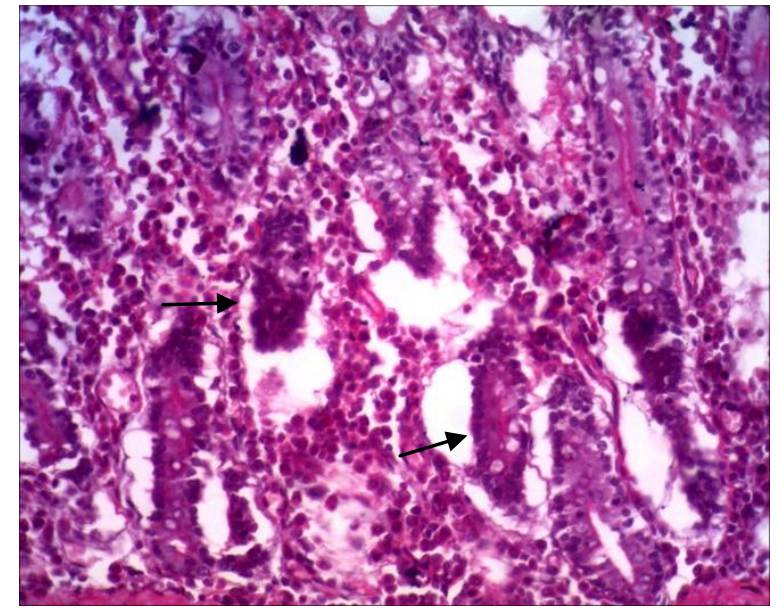

Gambar 2. Ileum babi 2 jam postmortem. Sebagian kelenjar memperlihatkan sel-sel epitel yang tampak gelap dan tersusun padat sehingga lumen kelenjar tidak tampak (anak panah) (400x).

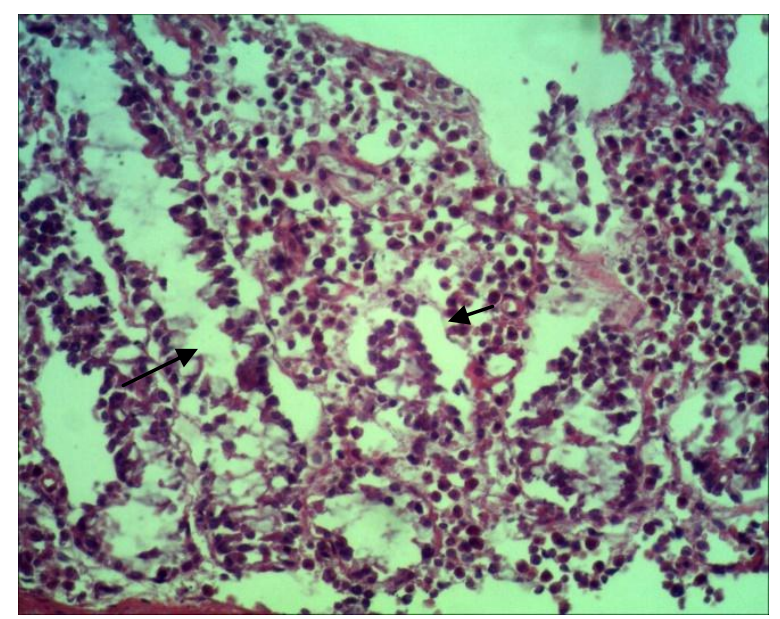

Gambar 4. Ileum babi 12 jam postmortem. Sebagian besar membran basalis kelenjar intestinal telah mengalami kerusakan (anak panah) (400x).

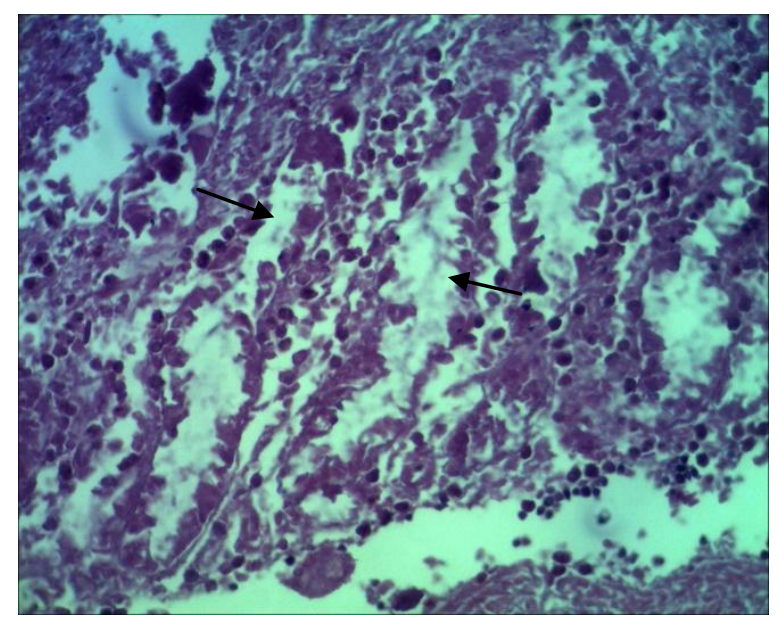

Gambar 6. Ileum babi 24 jam postmortem. Sebagian besar kelenjar intestinal telah mengalami lisis (anak panah). (400x). 


\section{BAHASAN}

Dalam

memperkirakan waktu kematian, dapat digunakan beberapa pendekatan, yaitu antara lain secara makroskopik dan mikroskopik. Penilaian secara makroskopik dilakukan dengan cara melihat tanda-tanda kematian dari jenazah, diantaranya ialah livor mortis, rigor mortis, algor mortis, dekomposisi, adipocere, dan mumifikasi. ${ }^{6,7}$

Untuk penilaian secara mikroskopik dilakukan dengan cara melihat dan menilai perubahan seluler sebagai akibat dari proses autolisis yang dimulai sejak kematian suatu organisme. Proses autolisis ini mencakup perubahan dalam bentuk, ukuran, kepadatan elektron, dan lokalisasi dari struktur sel, dan secara umum menyebabkan kehilangan keteraturan jaringan sel secara bertahap. ${ }^{8}$

Salah satu perbedaan antara usus halus dan organ saluran cerna lain seperti gaster, esofagus dan kolon yang hanya menunjukkan sedikit perubahan dalam beberapa jam pertama postmortem, villi dari usus halus sangat rentan terhadap proses autolisis. Sel epitel dari villus ditemukan terpisah dari membran dasar dalam waktu 5-10 menit awal setelah kematian organisme. $^{9}$

Hasil penelitian ini mendapatkan terbentuknya ruang subepitel pada 0 jam postmortem. Hal ini selaras dengan hasil penelitian yang dilakukan oleh Cross dan Kohler $^{10}$ yang menemukan bahwa pada babi konvensional, ruang subepitel terbentuk di seluruh bagian usus halus dalam waktu kurang dari 24 menit postmortem. Walaupun demikian, autolisis tidak terjadi secara seragam setelah pembentukan ruang subepitel yang cepat. Deskuamasi epitel menyeluruh terjadi dengan cepat pada duodenum dan jejunum, sedangkan deskuamasi pada ileum hanya terjadi pada bagian vilus sekitar 3 jam awal postmortem. Tingginya insidensi dari autolisis yang terjadi dalam waktu singkat pada usus halus membuatnya kurang dapat diandalkan dalam pemeriksaan postmortem apabila waktu setelah kematian telah berlangsung lama. ${ }^{11}$
Sebagai salah satu organ yang cepat mengalami perubahan histologik atau lisis postmortem, usus halus sebaiknya menjadi salah satu spesimen yang diperiksa lebih dahulu dalam pemeriksaan mikroskopis. ${ }^{10}$

Berdasarkan pengamatan dari penulis, perubahan histologik pada kelenjar intestinal ileum tidak terjadi secara serentak Kongesti maupun lisis dapat terjadi pada sebagian sel-sel kelenjar, sedangkan sebagian sel lainnya masih terlihat normal; hal ini sejalan dengan hasil penelitian Tomita et al. ${ }^{12}$

Ketidakseragaman dari perubahan histologik ini juga dapat dipengaruhi oleh perbedaan potongan pada sediaan histologi dari ileum yang digunakan sehingga menyulitkan penilaian perubahan histologik tersebut. Hal ini yang menjadi salah satu limitasi dari penelitian ini.

Penelitian serupa mengenai perubahan autolisis postmortem dilakukan juga oleh Hasan et al. ${ }^{13}$ pada organ jantung dan ginjal dari sapi bali dan ditemukan autolisis pada jantung terjadi 6 jam postmortem sedangkan ginjal mengalami autolisis pada 4 jam postmortem. Penelitian oleh Scheifele et al. ${ }^{14}$ menggunakan subjek usus halus dari tikus Wistar berusia 2 hari dan menemukan terjadinya nekrosis fokal dan sembab sel dalam kurun waktu 30 menit postmortem.

Thakur et al. $^{15}$ meneliti subjek 50 jenazah manusia baik jenis kelamin lakilaki maupun perempuan dengan kriteria inklusi yaitu waktu kematian diketahui, disetujui oleh keluarga, dan tidak menderita penyakit ginjal sebelum meninggal. Penelitian Thakur et al. menemukan bahwa perubahan degeneratif sedang dari ginjal mulai ditemukan pada 6 subjek dalam 12 jam pertama postmortem dengan suhu ruangan $10-20^{\circ} \mathrm{C}$. Sebagai perbandingan, penelitian oleh Rahmadana et al. ${ }^{16}$ dengan organ yang sama namun dengan subjek yang berbeda yaitu babi melaporkan bahwa perubahan struktur sel-sel tubuli proksimal dari ginjal mulai tampak pada 30 menit postmortem.

Hasil dari beberapa penelitian di atas berbeda dengan penelitian menggunakan 
usus halus bagian ileum dengan hewan coba babi yaitu ditemukannya perubahan pada struktur membran basalis dan kongesti kelenjar yang mulai tampak pada 2-3 jam postmortem hingga kerusakan pada sebagian besar membran basalis dan lisis pada selang waktu 12-16 jam postmortem. Perbedaan hasil penelitian yang didapatkan dapat disebabkan oleh perbedaan faktor hewan coba, organ yang diteliti, suhu ruangan, serta segmen preparat yang digunakan.

\section{SARAN}

Perlu dilakukan penelitian lebih lanjut dengan jumlah sampel yang lebih besar dan interval waktu yang lebih rinci serta menggunakan segmen lain dari usus halus maupun perbandingan dengan organ lain.

Diperlukan juga pembuatan sediaan preparat dengan beberapa potongan pada tempat atau segmen yang sama untuk memudahkan penilaian.

\section{DAFTAR PUSTAKA}

1. Death. Kamus Kedokteran Dorland. Ed 31. Jakarta: EGC; 2010. p.556

2. Khrisanti P. Perbedaan kecepatan lisis sel ginjal tikus wistar pada media tanah dan air tawar: berdasarkan gambaran histopatologi. Nov 2010. Available from: eprints.undip.ac.id/23650/

3. Eroschenko VP. Atlas Histologi diFiore: Dengan Korelasi Fungsional (11th ed). Jakarta: EGC, 2008; p. 303-10.

4. Sutoyo D. Histologi. Surakarta: Lembaga Pengembangan Pendidikan UNS \& UPT Penerbitan dan Percetakan UN, 2009; p. 139.

5. Swindle MM, Makin A, Herron AJ, Clubb FJ Jr, Frazier KS. Swine as models in biomedical research and toxicology testing. Veterinary Pathology. 2012;49(2):344-56.

6. Fitricia R. Tanda intravital yang ditemukan pada kasus tenggelam di Departemen Kedokteran Forensik Fakultas Kedokteran Universitas Sumatera Utara Rumah Sakit Umum
Pendidikan H. Adam Malik/Rumah Sakit Umum Daerah Piringadi Medan pada bulan Januari 2007-Desember 2009. 2010. [cited 2015 Oct 12] Available from: repository.usu.ac.id/bitstream/123456 789/21606/4/Chapter\%20II.pdf

7. Ammar M. Pengaruh lama waktu kematian terhadap kemampuan motilitas spermatozoa. Jurnal Media Medika Muda. 2013;2(1).

8. Van Cruchten S. Van Den Broeck W. Morphological and biochemical aspects of apoptosis, oncosis and necrosis. Anat Hist Embryol. 2002;31(4):214-23.

9. Herbert JK. Morphologic considerations in the interpretation of gastrointestinal disorders. Toxicol Pathol. 1988; 16(2):110-7.

10.Cross RF. Kohler EM. Autolytic changes in the digestive system of germfree, Escherichia coli monocontaminated, and conventional baby pigs. Can J Comp Med. 1969;33:108-12.

11.Loehry CA. Creamer B. Post-mortem study of small-intestinal mucosa. British Medical Journal. 1966;1:8279.

12.Scarpelli DG, Iannaccone PM. Cell death, autolysis and necrosis. Anderson's Pathology (9th ed). St Louis: Mosby, 1990; p. 13.

13.Hasan FA. Perbandingan autolisis organ jantung dan ginjal sapi bali pada beberapa periode waktu pasca penyembelihan. Indonesia Medicus Veterinus. 2015;4(4):305-13.

14.Scheifele D, Bjornson G, Dimmick J. Rapid postmortem gut autolysis in infant rats: potential problem for investigators. Can J Vet Res. 1987;51:404-6.

15.Thakur R, Goyal M, Bhawnani D. A study on estimation of time since death after histological examination of kidney. Int $\mathbf{J}$ Res Med Sci. 2015;3(5):1091-6.

16.Rahmadana B. Gambaran histologik ginjal postmortem pada hewan coba. eBm. 2014;2(2):413-8. 